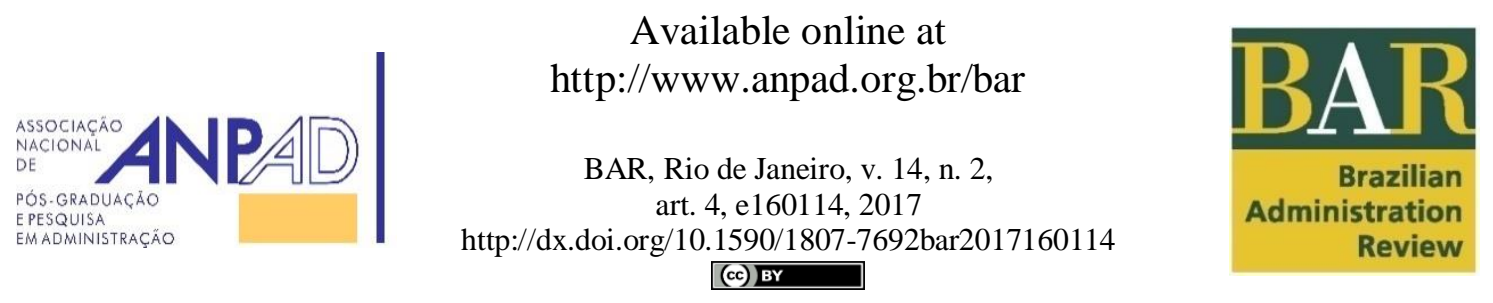

\title{
Business-Community Relationships for Extractive Industries: A Case Study in Peru
}

Jose Ventura ${ }^{1}$

Kety Jauregui ${ }^{1}$

Universidad ESAN ${ }^{1}$

Received 19 November 2016; received in revised form in 19 May 2017; accepted in 2 July 2017; first published online 24 July 2017.

Editor's note. Diogo Helal served as Action Editor for this article. 


\begin{abstract}
Natural resource-based economies have long relied on foreign demand to fuel their growth. For instance, the extractive sectors in Peru have experienced a rapid expansion, driven by a rising demand for commodities. Alongside economic growth, extractive operations have triggered social and environmental concerns among the various stakeholders, thus resulting in either social conflict or a deterioration of the relationship between companies in the extractive industries and local communities. In this context, the purpose of this paper is to understand the relationships between companies in the extractive industries and rural families. This research uses the case-study method. The findings show that a trustful relationship is supported by a beneficiary-society approach that builds upon philanthropic and ethical types of relationships. Unlike the type of relationship based on economic or legal interests, a trust-based relationship offers avenues for managing social conflict that have yet to be explored.
\end{abstract}

Key words: rural communities; extractive industries; social conflict; business-community relationships; Peru. 


\section{Introduction}

Over the last 15 years, extractive industries have gained momentum in Latin America (Damonte, Kuramoto, \& Glave, 2014) and contributed significantly to the growth of the gross domestic product (GDP) of economies in the region. For instance, Peru's extractive sector accounted for an average of $13.5 \%$ of its GDP over the last ten years (Banco Central de Reserva del Perú [BCRP], 2015) and made up about 62\% of total exports in 2014 (Superintendencia Nacional de Aduanas y Administración Tributaria [SUNAT], 2015). Clearly, the Peruvian economy depends heavily on extractive industries; likewise, the social and environmental impacts of these industries on rural communities are also of note. Peru's mining industry went from operating on 15 million hectares of community lands (Dorregaray, 2005) in 1993, to 81.72 million hectares in 2015 (Ministerio de Energía y Minas [MINEM], 2015a).

According to Peruvian government sources, by 2013 a great deal of lands occupied by 6,436 officially recognized peasant communities in Peru had been franchised to mining companies (Superintendencia Nacional de los Registros Públicos [SUNARP], 2016). Although the Peruvian economy grew 2.4\% in 2014, compared with $1.3 \%$ growth in Latin America and the Caribbean overall and 3.4\% growth worldwide during the same period (International Monetary Fund [IMF], 2015), the number of social conflicts resulting from the exploitation of natural resources increased much more substantially during the same period. As of October 2007, the Peruvian Ombudsman's Office had registered 80 social conflicts (Defensoría del Pueblo, 2007), and by November 2015 this figure had climbed to 215, of which 149 (69.3\%) were socio-environmental conflicts (Defensoría del Pueblo, 2015).

Thus far, a climate of distrust and a lack of cooperative relationships remain key challenges for extractive firms. The reactions of rural communities to extractive operations have become all the more delicate, thus leading to delays and/or the cancellation of projects, which in turn may compromise the producing country's economic health and, hence, prevent the government from fulfilling its mandate to develop the countryside. For instance Davis and Franks (2014) contend that company-community conflict triggered by environmental and social impacts can involve costs arising from temporary shutdowns or delays, of up to US \$20 million per week. At the same time, the greatest expenses are the opportunity costs due to planned future projects or expansion plans that stalled. For companies in the extractive industries, therefore, reconciling the needs and views of stakeholders (i.e., governments, local communities, employees, non-governmental agencies) with the company's own obligations to investors and showing how company activities can contribute both to GDP and to meaningful outcomes for local communities have become critical concerns to the prospect of earning the "social license to operate" (Deloitte, 2015, p. 6).

The literature on the relations between business and society shows two clearly different approaches. On the one hand, businesses seek to create goods and services to meet the needs of society, creating economic values for the company and satisfying the needs and wants of society. Companies are profitable as a result of the goods and services that they provide to society (Drucker, 1985; Friedman, 1962, 1970; Prahalad \& Hart, 2008; Porter \& Kramer, 2006). On the other hand, companies must share their profits with society. Companies must contribute directly to society because business activity negatively affects society; negative externalities (Coase, 1960) society assumes such liabilities, including environmental pollution, asymmetry of power, and social and economic inequities. In this case, society must be directly compensated by the company for its negative practices and effects on society (Ahlstrom, 2010; Bell \& Emory, 1971; Du, Bhattacharya, \& Sen, 2007, 2010; Freeman \& Phillips, 2002; Freeman \& Reed, 1983; Freeman, Wicks, \& Parmar, 2004; Garriga \& Melé, 2004).

Focusing a little more on the interaction between business and society, the literature describes the conflicted relationship between companies in the extractive industries and rural communities. Studies show the dimensions of the problem and the negative effects of such conflicts (Bebbington, 2013; Damonte et al., 2014; Davis. \& Franks, 2014; Nem Singh, 2012). However, these studies reveal little on the link between companies in the extractive industries and rural communities. The information 
available on the subject focuses on social conflicts and how they are managed but not on the underlying relationships themselves. Corporate social responsibility (CSR) seeks to bring companies in the extractive sector closer to rural communities. However, they do not study the type of relationships being built. Companies' CSR strategies are exclusively disputes about the environment, human rights or health and safety; rather, they are better understood as the control over the community and the right of community members to control the direction of their lives (Laplante \& Spears, 2008).

Furthermore, information on social responsibility has yet to penetrate deeply into the kinds of relationships built between businesses and rural communities (Altman, 1998; Damonte, 2008; Laplante $\&$ Spears, 2008; McKenna, 2016). Very little is known about the type of relationship there is between companies in the extractive sector and the members of communities, especially for the cases in which the literature indicates that the rural communities are not homogenous entities. Furthermore, Andean rural communities, as well as indigenous societies, are in the process of change. Significantly, the family and the community remain very intertwined concepts. Studies affirm that family is the most stable social entity within the rural communities (Castro, 2012). In this sense, the relationship between companies in the extractive sector and rural communities ends up being a relationship between the companies and rural families.

Hence, through the case study method this paper seeks to understand the relationships between companies and rural families. A review of the literature on the relationship between business and society opens the paper and includes a conceptual framework. The second part of the paper introduces the research method. The third part presents and compares findings related to two companies in the extractive sector. Finally, the fourth section discusses these findings and offers possible conclusions.

\section{Literature Review}

The relationship between business and society has been determined by the evolving conception of the business as a social entity. Companies (the basic units of the business sector) are commonly viewed as members of society; that is, the visible economic face of a social system (Steiner, 1971). In spite of this, the initial definitions of a business alluded to it as a vehicle of wealth creation that was independent from society (Friedman, 1962; Lucas \& Sargent, 1981). Nowadays, nonetheless, the multiplicity of linkages with other social agents requires firms to accept greater responsibility toward society.

The activities of business influence society by either inducing or preventing changes in the social system (Schumpeter, 1939). Business outcomes can contribute by providing inputs to meet social needs. They can also exert positive or negative influences on the local scenario in which they undertake their activities (neighboring communities). This latter aspect makes the social responsibility (SR) of a company a relevant issue, because the direct influence of businesses on society makes it likely for a business to accept the greater responsibilities that go along with this influence (Carroll, 1993; Garriga \& Melé, 2004). In so doing, companies adopt SR activities to create accountability and to demonstrate their concern for societal members' well-being and issues in a broader social context (Peloza \& Shang, 2011; Sen, Bhattacharya, \& Korschun, 2006).

Likewise, social influence on companies is paramount. Society, for example, provides a firm with qualified labor resources as well as consumers, both necessary for its very existence. This argument showcases the influence of society, which has also been contemplated within the frame of the stakeholder theory, whereby different parties or interest groups (consumers, employees, suppliers, or trade unions, to name a few) have a stake in the success of failure of a business (Parmar et al., 2010). Consumers, for instance, are capable of exerting scrutiny over companies' behavior. Over time, historical experience creates an evaluative context whereby consumers can elicit positive/negative associations that increase/decrease their sense of trust (Bhattacharya \& Sen, 2003, 2004; Ellen, Webb, \& Mohr, 2006). Furthermore, on a society-wide level, enhanced firms' exposure makes scrutiny a 
potential source of perceived social irresponsibility and, hence, the loss of trust, which can undermine consumer-related outcomes such as purchases and loyalty (Klein \& Dawar, 2004).

Recent research in management and ethics, however, contends that stakeholder theory, as a view of the relationship between business and society, is rather business-centric and market-oriented than stakeholder-oriented. Following this line of thought, Laczniak and Murphy (2012) and Hillebrand, Driessen and Koll (2015) are among the scholars who advocate for a view that acknowledges the multiplicity of relationships of companies with different stakeholders and who call for more prosociety and proenvironment perspectives regarding the ways companies both relate to societal members and conduct their activities.

Notwithstanding the fact that the extant business-stakeholder literature addresses a progression towards more balanced kinds of relationships, for example, those between companies and groups within society (key stakeholders) are often given a short shrift, as occurs with local communities and families (the most basic unit in any society). Alternate streams of thought started in the 60s, with the seminal works by Friedman $(1962,1970)$ and Porter $(1980)$, who first referred to society as a consumer of business activity, as well as the study by Bell and Emory (1971), who referred to society as a beneficiary of business activity.

Specific criteria signal how a company approaches society. Thus, a company that approaches society as a consumer society pursues specific business objectives. These include (a) maximizing profits and redistributing them among its stockholders, (b) providing goods and services to meet the needs of society, and (c) perceiving society as its real and potential market (Drucker, 1985; Friedman, 1962, 1970; Hillman \& Keim, 2001; Prahalad, \& Hart, 2008; Porter \& Kramer, 2006). In contrast, a company that approaches society as a beneficiary society possesses a different strategy. It seeks to (a) maximize its profits and simultaneously share them with select stakeholders, (b) compensate and remedy the damages it has created in society, (c) perceive society as a vulnerable entity lacking basic needs (Ahlstrom, 2010; Bell \& Emory, 1971; Du et al., 2007, 2010; Freeman \& Phillips, 2002; Freeman \& Reed, 1983; Freeman et al., 2004; Garriga \& Melé, 2004).

\section{Society as a Consumer Perspective}

Businesses serve the consumer society by running the business well and in accordance with both the rule of law and ethical customs. From this stance, SR is subsidiary to profit maximization as stated by Friedman, who in 1962 wrote that "businesses only have one SR: to use their resources and engage in activities designed to increase their profits so long as they stay within the rules of the game, i.e., operate in open and free competition without deception or fraud" (Friedman, 1962, p. 133). Although Friedman's view has been repeatedly challenged, it is important to note that he is one of the main proponents of the stockholder theory; a business-ethics theory concerning businesses and the behavior of business people, which does not preclude social interest (Hasnas, 1998). As such, the long-term benefit of investors makes it possible for a company to invest in product innovation and, thus, to deliver high-value products that improve people's standards of living, in addition to goals other than profit alone. That is, as businesses develop new goods and/or services that generate economic growth, they also deliver important benefits to society (Ahlstrom, 2010).

Thus, business meets society's needs, and society is a major consumer of goods and services produced by companies. Porter (1980) contended that companies have a duty to maximize value creation, that is, to create value for the customer. This translates into a difference between the production costs for a product or service and the price people accept to pay for that product or service. In this view, the purpose of business is not limited to making a profit but instead to search for competitiveness, which entails making more and better products for the benefit of society (Husted \& Salazar-Cantú, 2006), provided that families and individuals are able to consume affordable, high-quality goods and services. 
All in all, the initial conceptualizations of SR presented the business within a context of freedom and open competition as a stockholder-centered, law-abiding entity with no social obligation beyond making a profit (Friedman, 1962). Social responsibility was regarded as a tool for accomplishing the firm's economic goals of greater productivity and wealth creation (Carroll, 2008; Garriga \& Melé, 2004; Hillman \& Keim, 2001; Husted \& Salazar-Cantú, 2006). Soon after, interdependence grew between business and society as consumers shed light on businesses' responsibility for their economic and marketing functions of rendering goods and services and on the observations society's values and customs, leaving other considerations to philanthropy (Friedman, 1962). In addition, Drucker (1985) stated that the responsibility of a company is to generate profit so it can be sustainable:

A company that does not earn a profit that is at least equal to its cost of capital is irresponsible because it wastes society's resources. Good economic performance is the foundation without which the company cannot meet any of its other responsibilities (p. 13).

Note that, under the society-as-a-consumer approach, the scope of social responsibility links the economic and marketing functions of firms to law-abiding and ethical considerations (Robin \& Reidenbach, 1987).

\section{Society as Beneficiary Perspective}

Business also benefits societal members in ways that do not collide with obligations to shareholders. Engaging employee recruitment that live in the community, partnering with local suppliers, improving workplace conditions, and building roads and basic infrastructure are among the many activities that go beyond both legal requirements and wealth-creation for shareholders, and yet they are intertwined with profit-oriented practices. That is, to produce goods and services, a company must engage in activities likely to have a positive impact on different stakeholders or societal groups with a legitimate interest in the success or failure of the business (Parmar et al., 2010). Moreover, while doing so, the company is also ensuring the means for achieving profits (Daou \& Sarkis, 2013). Subsequently, under the approach in which society is a beneficiary, a business's main goal is profit maximization, although other stakeholder-related goals are also possible. Some such goals might be mandatory, for they are of critical importance to attaining the resources firms need to be profitable and competitive (Connelly, Ketchen, \& Slater, 2011), as is the case wherein technical capabilities are rendered by qualified employees, materials and services are provided by suppliers, and so forth.

Conversely, in a free-market economy, companies seek to minimize production costs to maximize profits and remain competitive (Roarty, 1997). Often, this entails shifting part of the actual production costs to the community rather than paying for them. These so-called social costs or negative externalities are what business are not willing to pay for, otherwise costs will increase and reduce profitability and competitiveness. Ultimately, such costs are paid for by society. In a way, business activity harms certain social sectors, has negative consequences including social and cultural conflicts, and may provoke social imbalances, among other undesired outcomes (Carroll, 2008). An unstated assumption is that business' activities harm society in one way or another. Thus, SR takes on another hue that is no longer inherent to business activity, because it emerges as a collateral response of the business against the social costs it creates in its efforts to gain legitimacy from society (Melé, 2008). Figure 1 describes the business society relationship approaches. The upper and lower vertices represent the two proposed social arrangements: (a) business-consumer society, and (b) business-beneficiary society. 


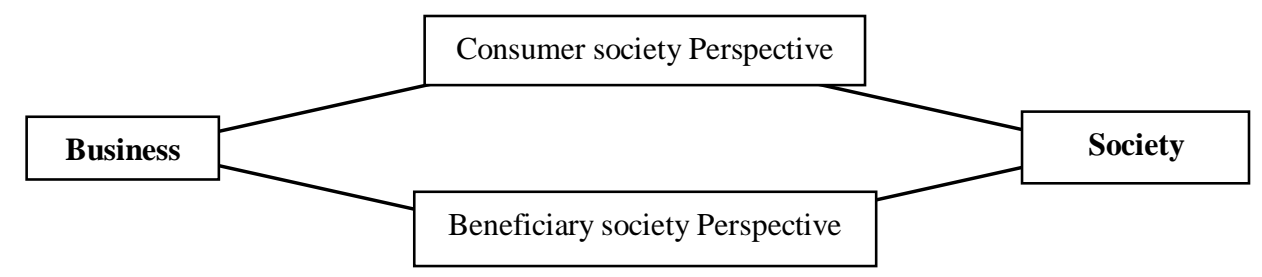

Figure 1. Business - Society Perspective

Source: Elaborated by the authors.

\section{Relationships between Businesses and Rural Families}

Both the previous approaches delve further into the business-society relationship. Neither of them, however, addresses in a straightforward manner the relationship between companies and subsets within society, like a local community or a family, the latter being not only the basic unit of society but also a key entity within the microeconomic scenario. Families constitute the demand side of the market: they consume to satisfy their needs and wants. They are also part of the supply side of the market: they produce goods and services for society and businesses alike. Hence, families play a key role in business development so that their interests cannot be viewed as contrary to those of powerful companies. To this extent, Carroll (1979) and, later on, Porter and Kramer (2002, 2006, 2011) further investigated the nature of the society-as-consumer and the society-as-beneficiary relationships, in attunement with the evolving concept of SR. To them, companies and families (or communities) can enact relationships of four types: economic, legal, ethical, and philanthropic.

From a microeconomic viewpoint, Maddala and Miller (1991) have contended that, on the one hand, the business is a unit of production of goods and services that meets the needs of society and, on the other hand, they assert that the family is an economic agent that consumes, saves, invests, and provides labor. The two units are parts of society.

As consumers of goods and services produced by business, families form the company's most attractive market. Businesses meet household food, housing, health, education, mobility, and entertainment needs. Families cannot be regarded as opponents or antagonists of productive business interests but are rather one of the business' most important partners and the ultimate beneficiaries of all business activities. To that extent, the relationships between business and families, whether the latter are regarded as consumers or beneficiaries, are of four types: economic, legal, ethical, and discretionary or philanthropic (Carroll, 2003).

Business must produce the goods and services that families need or want and sell them at a reasonable price. The company thus benefits financially, meets its expectations, perpetuation of self, grows, and makes a profit for its shareholders (Carroll, 2008). Therefore, in an economic relationship, a company provides goods and services required by families, whereas families elicit positive associations which lead to consumer-related outcomes. Other SR actions, such as cause-related marketing, or basic infrastructure projects, to name a few, can be seen as strategic philanthropy.

The business' second responsibility is legal (Carroll, 1979, 2003). Having a legal responsibility implies that business and families abide by a body of existing laws. If a rift appears between families and business, both parties can resort to legal procedures to resolve their dispute (Carroll, 2003). Porter and Kramer (2006, p. 5) call it the license to operate: "The notion of license to operate is derived from the fact that every company needs tacit or explicit governments, communities and several other stakeholders' authorization to do business". Therefore, in a legal relationship, governments establish a legal and regulatory environment that companies must comply with. However, that is not the extent of their social responsibility. Companies can abide by other mechanisms: the attainment of the social license to operate, commonly found in extractive industries (Moffat \& Zhang, 2014); the adoption of 
SR practices championed at the industry level and voluntary concern with international endeavors (e.g. the Global Reporting Initiative, the UN Global Compact), among other social causes.

Ethical responsibilities include decisions, practices and duties for which societal members (business agents included) are accountable, and these must be validated in accordance to the moral values that society at large has agreed upon. Thus, ethical responsibilities are to reflect the values and emerging standards that society expects from businesses. Consequently, a company's ethical responsibilities are always under scrutiny and subject to public debate because their legitimacy depends on society. From the business standpoint, the extent of SR depends on voluntary commitments determined by business' understanding of their impacts, either positive or negative, on society (Maon, Lindgreen, \& Swaen, 2010; Safwat, 2015). Therefore, a relationship based on ethical responsibilities includes the non-statutory activities and practices that members of society allow or prohibit (Carroll, 1991, 2003). A clear distinction exists between relationships based on legal responsibilities and those based on ethical responsibilities. Legal responsibilities are required and mandatory, whereas ethical responsibilities involve value-guided acts (Carroll, 1993, 2003) and imply a moral obligation (Porter \& Kramer, 2006).

Regarding discretionary responsibilities, Carroll (2003) mentions those that are subject to a business' discretionary decisions. Such responsibilities are completely voluntary and are guided solely by the desire of entrepreneurs to engage in social activities. These are actions that are neither required by law nor expected by society but that the company undertakes out of a sense of charity or philanthropy, nonetheless. Although philanthropy is often regarded as the oldest form of corporate SR, nowadays companies consider their SR activities to be an investment that should yield a social return (Godfrey, 2005); in fact, Porter and Kramer (2006) argued that philanthropy should be strategic and support the competitive environment of the company. All in all, managing to build up a good corporate reputation reinforces the company's brand image (Kapelus, 2002). In this context, Hillman and Keim (2001) and Du, Bhattacharya and Sen $(2007,2010)$ pointed out how social action may lead to relational outcomes such as customer loyalty, identification with the company and its products, and even brand advocacy, particularly if consumers or families are aware of a company's SR actions and interpret them as being driven more by intrinsic motives and less by business serving or extrinsic motives. However, in a nonstrategic philanthropic relationship, companies voluntarily commit themselves to give of their own resources (or those that they can leverage) to support a certain action in order to achieve a social aim (Mihaljevic \& Tokic, 2015) without being concerned about promoting business objectives (Diener, 2013), as is the case with strategic philanthropy. Figure 2 describes the relationship between companies in the extractive sector and families. The company and family appear at the left and right side of the figure. Carroll's four social relations (Economic, Statutory, Ethical, Philanthropic) are represented.

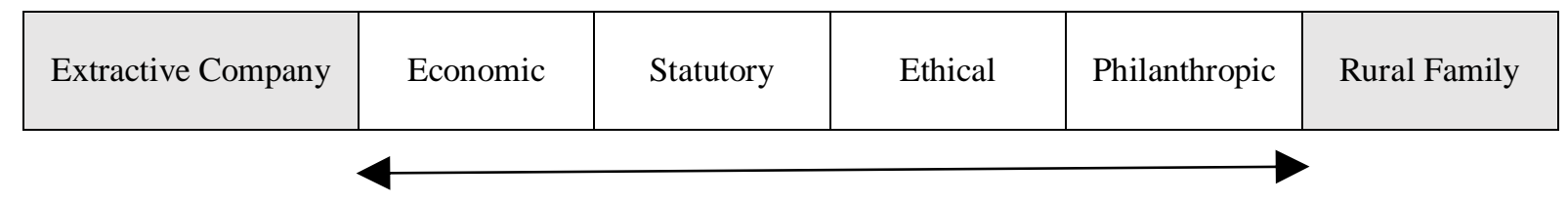

Figure 2. Company - Family Relationship

Source: Elaborated by the authors.

The conceptual framework was introduced by combining the aforementioned perspective with the types of relationships existing between business and society. Figure 3 describes the company-family relationship. The business appears on the far left and families on the right. The approaches to the relationship between the company and the family are (a) business consumer society (top of the figure) and (b) business beneficiary society (bottom of the figure). The types of relationship between companies and families are represented within the figure. 


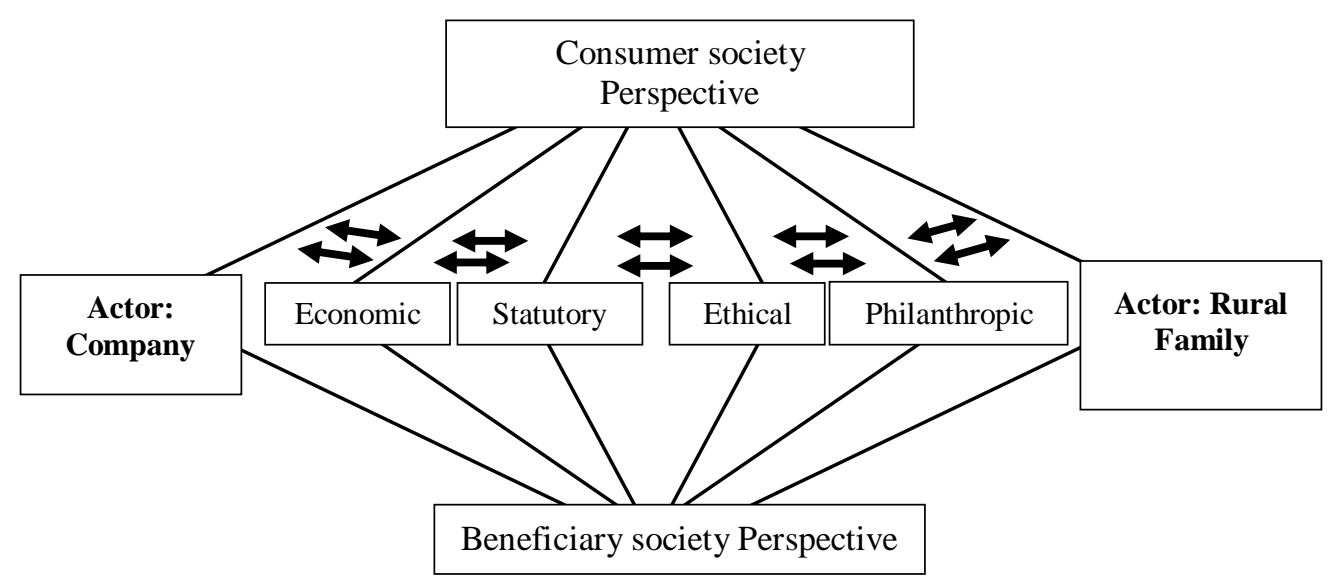

Figure 3. Business-Family Relationship

Source: Elaborated by the authors.

\section{Method}

This study applies a qualitative research method that seeks to approach as much as possible the viewpoint of the participants under study (Creswell, 2013; Norman \& Lincoln, 2005; Strauss, 1987). The case-study method is used because of the following reasons: (a) it can easily be used to ask how companies and families relate to each other (Yin, 1994); (b) it has a specific character; for example, it can be used to study the company-family relationship (Stake, 1995); (c) it is limited to a defined context (Peru, in this case) (Creswell, 2013; Stake, 1995); and (d) it can describe behaviors that can be included in conceptual frameworks, in this case, the company-family relationship (Stake, 1995).

\section{Setting}

The study was conducted in Peru, an emerging economy largely reliant on two extractive industries (mining and natural gas). In Peru, there is a long history of social conflict in relation to extractive operations conducted in areas where numerous rural communities were engaged in traditional economic activities (mainly agriculture and livestock). Although surrounded by a richness of natural landscapes and hydrocarbon deposits (in the forest) and minerals (in the Andean region), the vast majority of communities either live below the poverty line or have their basic needs unmet. Cajamarca presents an incidence of extreme poverty of 15 to $23 \%$ and Ucayali of 1.1 to $3 \%$; in contrast, Lima, capital of Peru, presents an incidence less than $0.8 \%$ (Instituto Nacional de Estadística e Informática [INEI], 2015).

Peru ranks first for gold production and second for copper and silver production in Latin America. It ranks third for copper and silver production worldwide (MINEM, 2015b). Investment in extractive industries has been a key driver of economic growth: the industry grew from US \$ 1609.9 million in 2006 to US \$ 8893.7 million in 2014 (MINEM, 2015a). Exports rose from US \$ 17.2 billion in 2005 to US \$ 38.3 billion in 2014 (BCRP, 2015), and mining exports rose from $81.79 \%$ of total exports in 2005 to $82.06 \%$ in 2014 (MINEM, 2015a). In Peru, natural gas is the third-largest source of energy, after oil and coal. Natural gas reserves currently grow at a rate of 5\% a year (Organismo Supervisor de la Inversión en Energía y Minería [OSINERGMIN], 2008). Main deposits are located in the departments of Cusco, Piura, and Ucayali. Output increased from 1376.5 bcf in 2001 to 418794.8 bcf in 2012 (INEI, 2015). Also, in Lima gas consumption rose from 318 connected users in 2008 to 395,000 connected users in 2016. These figures depict not only exponential growth but also the growing importance of this source of energy for consumers and industry alike.

Thus, it was chosen to conduct the study in both departments of Peru: Ucayali and Cajamarca. The department of Ucayali (Amazon rainforest), which hosts natural gas operations, and the department 
of Cajamarca (Andean highlands), which hosts gold-mining operations. Moreover, the rate of poverty reaches $70 \%$ of rural population in Cajamarca and 50\% of the same population in Ucayali.

\section{Data gathering}

For the purpose of this research, companies were selected in the extractive sector whose main characteristic was that they had a direct relationship with rural families through their SR programs. Four criteria were used to select the companies: (a) the company should operate in an area where the population is mostly rural, (b) the company should be involved in social conflicts, (c) the company should operate in the rural highlands or the rural jungle, and (d) the company should operate in the mining and/or hydrocarbon-extraction industry. The Table 1 identifies some characteristics of these companies.

Table 1

\section{Company Characteristics}

\begin{tabular}{lll}
\hline \multicolumn{1}{c}{ Company } & \multicolumn{1}{c}{ Yanacocha } & Aguaytía \\
\hline Sector & Extractive & Extractive \\
\hline Location & Rural Andes & Rural rainforest \\
& Cajamarca & Ucayali \\
\hline Size of company & Large & Intermediate \\
\hline Products or services & Gold mining & Natural gas energy \\
\hline Shareholders & Newmont & Maple Energy \\
& Buenaventura & \\
\hline Industry ranking & Largest Latin American Exporter in 2014 & Second largest national producer in 2012 \\
& Largest National Producer in 2014 & \\
\hline
\end{tabular}

Note. Source: Prepared by the authors.

The families interviewed were chosen according to certain criteria from the databases of the selected companies. Families were prioritized that (a) had worked and/or had direct relations with the given companies for over three years, and (b) lived in poverty (income of less than two dollars per day) prior to having initiated a relationship with the company. Were identified 60 families in total, 30 from each company. Next, each family filled out a brief questionnaire on their socioeconomic condition (family income, composition, formal education, basic needs met). The frame of reference for the questionnaire was the National Household Survey (ENAHO, http://www.ipe.org.pe/enaho, retrieved September, 1, 2015). Afterward, descriptive statistics were utilized to process the data collected and to classify the rural families according to their socioeconomic situation. This procedure allowed us to control for (a) information incomplete by more than $40 \%$ and (b) families that were not in a poverty situation at the time they initiated their relationship with the given company. As a result, were selected a total of 30 families (15 in Cajamarca and 15 in Ucayali) that had similar socioeconomic conditions and an enduring relationship with the company. Of the 15 selected, only 10 families were interviewed for each company for a total of twenty families. It should be noted that sample size is related to data collection; as the interviews are carried out, codes are identified and it is decided whether more interviews are needed or not. The saturation is achieved after ten interviews, because no new information emerges. In addition, two managers from each company were interviewed for a total of four in-depth interviews with managers.

Were prepared two interviewing guides: one for families and another for company managers or community relations. The interviewing guide for families was about (a) family background, (b) general perceptions of the company's extractive operations as well as of the role played out by private investment, (c) the relationship with the company, (d) the perceived socioeconomic changes up to the 
date, and (e) an appraisal of basic needs that had been met up to the date. In the case of the interviewing guide for managers or community relations, the questions were in regards to (a) the activities of the company and its area of socio-environmental influence, (b) key stakeholders, (c) the relationship with social stakeholders, mainly local communities, and (d) an appraisal of the role played out by the company to improve the socioeconomic conditions of local communities within the company's direct area of influence.

Finally, an adult informant was identified in each family through prior contacts and with the help of the company family-liaison managers. The interview was scheduled at the homes of the families, because it was wanted to build trust with the families. Interviews took two hours, on average. After interviewing the families, were scheduled two interviews with the companies' SR managers. On average, the interviews with the companies' SR managers too lasted 2 hours.

Data collection was triangulated to determine the consistency of the results, namely, by using socioeconomic surveys, in-depth interviews, secondary information provided by companies, and the managers' views of the families interviewed. The interviews were recorded and transcribed. A description of the characteristics of the informants, the location of the interviews, the process of selecting the interviewed families were all logged to demonstrate the reliability and validity of the qualitative research, as per Guba and Lincoln (1989).

\section{Data analysis}

For data analysis, Corbin and Strauss's (2008) grounded theory was used. First, the interviews were transcribed and then organized by category and code type. To identify the codes, each paragraph of the interview was read and the codes emerged. For example, from the phrase, "The company builds roads and provides health services..." and the phrase, "The company has helped us with loans..." emerged the code, The company becomes the main source of financing. In addition, the literature was reviewed each time a code was identified. For example, the code that emerges from literature review is Family meets its needs. In summary, codes are identified from both literature review and interviews. Then, the codes were grouped in order to identify categories. For example, Company affects people and Family meets its needs were grouped into the category of beneficiary society. Next, the categories were integrated in the interest of explain the business-community relationships for extractive industries. Atlas TI software was used as support. Finally, each case study (Yanacocha and Aguaytia) was reported individually, following which was made a comparative (cross-case) analysis.

\section{Findings}

This section presents the results obtained using the method described above. In addition, it includes an analysis of the findings for both cases studied. For both cases, the types of relationships between the company and the rural families within the company's influence are identified. The relationships are analyzed through the lenses of Carroll's hierarchical pyramid: economic, legal, ethical and philanthropic relationships (Carroll, 2003). Finally, findings from both cases are compared and analyzed. 


\section{Relationship between Yanacocha Mining Company and Rural Families}

The relationship between the Yanacocha mining company and rural families can be described as Beneficiary society. The interviewees identified the following characteristics: (a) the company perceives its own influence on rural communities, (b) the managers perceive families' demands for compensation from the company, (c) the company is the main source of financing for the rural communities, (d) SR helps to prevent social conflicts, (e) families perceive themselves as beneficiaries of the company's interventions, and (f) contributing to rural community development is a necessary collateral of mining. Table 2 outlines the relationship between Yanacocha and rural families based on the information gathered in the interviews.

Table 2

Relationship between Yanacocha and Rural Families

\begin{tabular}{|c|c|c|c|}
\hline Category & $\begin{array}{c}\text { Code } \\
\text { (framework) }\end{array}$ & Code (evidence) & Evidence \\
\hline \multirow[t]{8}{*}{$\begin{array}{l}\text { Beneficiar } \\
\text { y society }\end{array}$} & \multirow[t]{2}{*}{$\begin{array}{l}\text { Company } \\
\text { affects } \\
\text { people }\end{array}$} & $\begin{array}{l}\text { The company perceives its } \\
\text { own influence on rural } \\
\text { communities }\end{array}$ & $\begin{array}{l}\text {. "If you divert a channel and the community } \\
\text { no longer has access to the same amount of } \\
\text { water, the company artificially replenishes } \\
\text { access to water. The company has a } \\
\text { resettlement plan and a compensation } \\
\text { package" (Manager 1, Yanacocha). }\end{array}$ \\
\hline & & $\begin{array}{l}\text { Management perceives } \\
\text { families demands for } \\
\text { compensation from the } \\
\text { company }\end{array}$ & $\begin{array}{l}\text {. "People have a 'give me' attitude toward the } \\
\text { company and the compensation it provides to } \\
\text { families affected by the mine" (Manager } 2 \text {, } \\
\text { Yanacocha). }\end{array}$ \\
\hline & \multirow[t]{2}{*}{$\begin{array}{l}\text { Families } \\
\text { meet their } \\
\text { needs }\end{array}$} & \multirow[t]{2}{*}{$\begin{array}{l}\text { The company becomes the } \\
\text { main source of financing. }\end{array}$} & $\begin{array}{l}\text {."The company builds roads and provides } \\
\text { health services in the community affected" } \\
\text { (Manager } 1 \text {, Yanacocha). }\end{array}$ \\
\hline & & & $\begin{array}{l}\text {. "The company has helped us with loans .... } \\
\text { The first loan was two thousand soles, after that } \\
\text { was a loan of four thousand soles. This was } \\
\text { great support" (Family } 8 \text {, Yanacocha). }\end{array}$ \\
\hline & \multirow[t]{3}{*}{$\begin{array}{l}\text { Families get } \\
\text { support }\end{array}$} & \multirow{3}{*}{$\begin{array}{l}\text { SR seeks to prevent social } \\
\text { conflict. } \\
\text { Families regard themselves } \\
\text { as beneficiaries of the } \\
\text { company's interventions. }\end{array}$} & $\begin{array}{l}\text {."For example, the guinea pig (farm) project } \\
\text { helps to maintain good relations. The company }\end{array}$ \\
\hline & & & $\begin{array}{l}\text { can keep your operations going” (Manager 2, } \\
\text { Yanacocha). }\end{array}$ \\
\hline & & & $\begin{array}{l}\text {. "They have given us a loan for a business } \\
\text {... I hope they will keep on helping me" } \\
\text { (Family } 1 \text {, Yanacocha). }\end{array}$ \\
\hline & $\begin{array}{l}\text { Collateral to } \\
\text { business } \\
\text { activities }\end{array}$ & $\begin{array}{l}\text { Promoting development is a } \\
\text { necessary collateral of } \\
\text { company's activities. }\end{array}$ & $\begin{array}{l}\text {."We carry out programs and projects that go } \\
\text { beyond the Yanacocha operation" (Manager } 2 \text {, } \\
\text { Yanacocha). }\end{array}$ \\
\hline
\end{tabular}

Note. Source: Prepared by the authors.

\section{Type of relationship between Yanacocha mining company and families}

Yanacocha established a philanthropic, ethical, legal relationship with rural families (see Figure 4). 


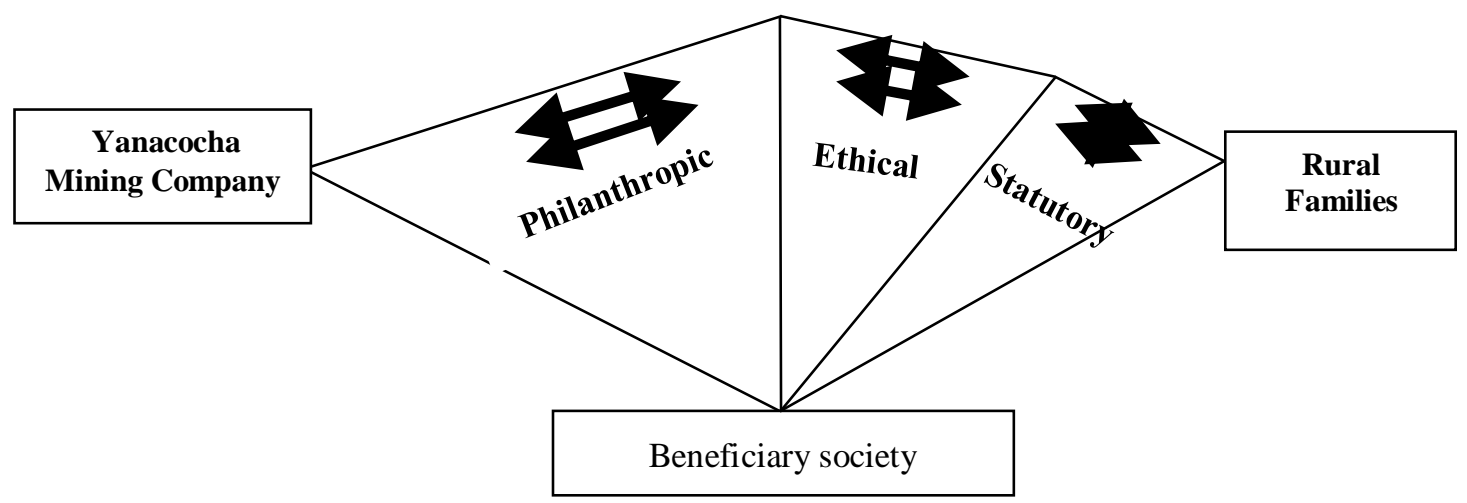

Figure 4. Type of Relationship between Yanacocha and Rural Families Source: Prepared by the authors.

The interviewees argued that (a) the company follows the rules set forth by the stakeholders, (b) its SR policy contributes to sustainable development, (c) the company provides discretionary and voluntary support, and (d) the company seeks to improve its reputation. Table 3 outlines the type of relationship that exists between Yanacocha and rural families based on the information gathered in the interviews.

Table 3

Relationship between Yanacocha Mining Company and Rural Families

\begin{tabular}{|c|c|c|c|}
\hline Category & Code (framework) & Code (evidence) & Evidence \\
\hline Legal & Social license & $\begin{array}{l}\text {. Company follows } \\
\text { stakeholders' principles }\end{array}$ & $\begin{array}{l}\text { "The company seeks to respect existing } \\
\text { standards of its stakeholders: its owners" } \\
\text { (Newmont, World Bank). (Manager 2, } \\
\text { Yanacocha). }\end{array}$ \\
\hline Ethical & $\begin{array}{l}\text {. Voluntary respect } \\
\text { for the social and } \\
\text { environmental context }\end{array}$ & $\begin{array}{l}\text { - SR as a contribution to } \\
\text { sustainable development }\end{array}$ & $\begin{array}{l}\text { "The company meets more than it is } \\
\text { committed to the environmental impact } \\
\text { study" (Manager 1, Yanacocha). }\end{array}$ \\
\hline \multirow[t]{2}{*}{$\begin{array}{l}\text { Philanthro } \\
\text { pic }\end{array}$} & $\begin{array}{l}\text { - Discretionary, } \\
\text { voluntary }\end{array}$ & \begin{tabular}{lr}
\multicolumn{1}{c}{ Company } & provides \\
discretionary & and \\
voluntary support &
\end{tabular} & $\begin{array}{l}\text { "They have helped us .... The first loan } \\
\text { was two thousand (Peruvian currency) } \\
\text { soles .... That helped us" (Family 3, } \\
\text { Yanacocha). }\end{array}$ \\
\hline & $\begin{array}{l}\text { - Seeks to enhance } \\
\text { corporate reputation }\end{array}$ & $\begin{array}{l}\text { Company seeks to } \\
\text { enhance its reputation }\end{array}$ & $\begin{array}{l}\text { "When we created ALAC, we said we } \\
\text { should do right by doing our best and not } \\
\text { brag" (Manager 2, Yanacocha). }\end{array}$ \\
\hline
\end{tabular}

Note. Source: Prepared by the authors.

\section{Relationship between Aguaytía Energy and Rural Families}

The relationship between Aguaytía Energy and rural households combines the approaches of the consumer society and the beneficiary society. After analyzing the interviews with managers and families, was characterized the company-family relationship as follows: (a) the relationship with the population serves two objectives: profitability and sustainable development; (b) the company cofinances projects (to which beneficiaries are also asked to contribute); (c) social responsibility is a way to protect the company's operations; (d) families bring their needs to the company; (e) the company co- 
finances or supports the population; (f) the people perceive themselves as beneficiaries. Table 4 outlines the relationship between Aguaytía and rural families based on the information gathered in the interviews.

Table 4

Relationship between Aguaytía Energy Company and Rural Families

\begin{tabular}{|c|c|c|c|}
\hline Category & $\begin{array}{c}\text { Code } \\
\text { (framework) }\end{array}$ & Code (evidence) & Evidence \\
\hline \multirow[t]{3}{*}{$\begin{array}{l}\text { Consumer } \\
\text { society }\end{array}$} & $\begin{array}{l}\text { Company } \\
\text { profits }\end{array}$ & $\begin{array}{l}\text { Two-pronged } \\
\text { relationship with the } \\
\text { people: returns and } \\
\text { sustainable } \\
\text { development }\end{array}$ & $\begin{array}{l}\text { "We have donated around } 50,000 \text { stoves to housewives } \\
\text { who previously used firewood. That has to do with our } \\
\text { business" (Manager 2, Aguaytía). }\end{array}$ \\
\hline & $\begin{array}{l}\text { Company } \\
\text { provides } \\
\text { services or } \\
\text { products }\end{array}$ & $\begin{array}{l}\text { Natural and liquefied } \\
\text { gas }\end{array}$ & $\begin{array}{l}\text { "We sell fuel. But there is an environmental and social } \\
\text { side: housewives use firewood with the side effects of } \\
\text { pollution and lung disease" (Manager 2, Aguaytía). }\end{array}$ \\
\hline & $\begin{array}{l}\text { Company } \\
\text { perceives } \\
\text { families as } \\
\text { attractive } \\
\text { market } \\
\text { (clients) }\end{array}$ & $\begin{array}{l}\text { Company co- } \\
\text { finances projects and } \\
\text { requires } \\
\text { contributions from } \\
\text { beneficiaries }\end{array}$ & $\begin{array}{l}\text { "The farmer has a water well and I say: Look, I'm going } \\
\text { to help you buy a power pump. I'll buy the conversion } \\
\text { kit that will cost me } \$ 1150 " \text { (Manager } 2 \text {, Aguaytía). }\end{array}$ \\
\hline \multirow[t]{4}{*}{$\begin{array}{l}\text { Beneficiary } \\
\text { society }\end{array}$} & $\begin{array}{l}\text { Company } \\
\text { affects people }\end{array}$ & $\begin{array}{l}\text { SR to prevent harm to } \\
\text { company's } \\
\text { operations }\end{array}$ & $\begin{array}{l}\text { "A company principle is to 'live and let live.' The } \\
\text { people live in peace and they let the company operate" } \\
\text { (Manager } 1 \text {, Aguaytía). }\end{array}$ \\
\hline & $\begin{array}{l}\text { Family meets } \\
\text { its needs }\end{array}$ & $\begin{array}{l}\begin{array}{l}\text { Families share their } \\
\text { needs } \\
\text { companies }\end{array} \\
\text { with }\end{array}$ & $\begin{array}{l}\text { "They give us technical advice. When I started raising } \\
\text { animals, they died because there wasn't a veterinarian, } \\
\text { but an engineer of the mine came to talk and the fish } \\
\text { farms now have come true" (Family 4, Aguaytía). }\end{array}$ \\
\hline & $\begin{array}{l}\text { Families get } \\
\text { support }\end{array}$ & $\begin{array}{l}\text { Companies become a } \\
\text { source of financing }\end{array}$ & $\begin{array}{l}\text { "They had no money to buy the whole system, so we } \\
\text { donated the entirety" (Manager } 2 \text {, Aguaytía). }\end{array}$ \\
\hline & No returns & $\begin{array}{l}\text { The company } \\
\text { perceives people as } \\
\text { beneficiaries. }\end{array}$ & $\begin{array}{l}\text { "The programs we have developed are for them; the } \\
\text { transportation program has benefitted forty to fifty } \\
\text { percent (of the people), and stove donations, another } \\
\text { twenty five percent" (Manager } 1 \text {, Aguaytía). }\end{array}$ \\
\hline
\end{tabular}

Note. Source: Prepared by the authors.

\section{Type of Relationship between Aguaytía energy group and rural families}

The relationship between the Aguaytía Energy Group and families can best be described as ethical and economic (see Figure 5). 


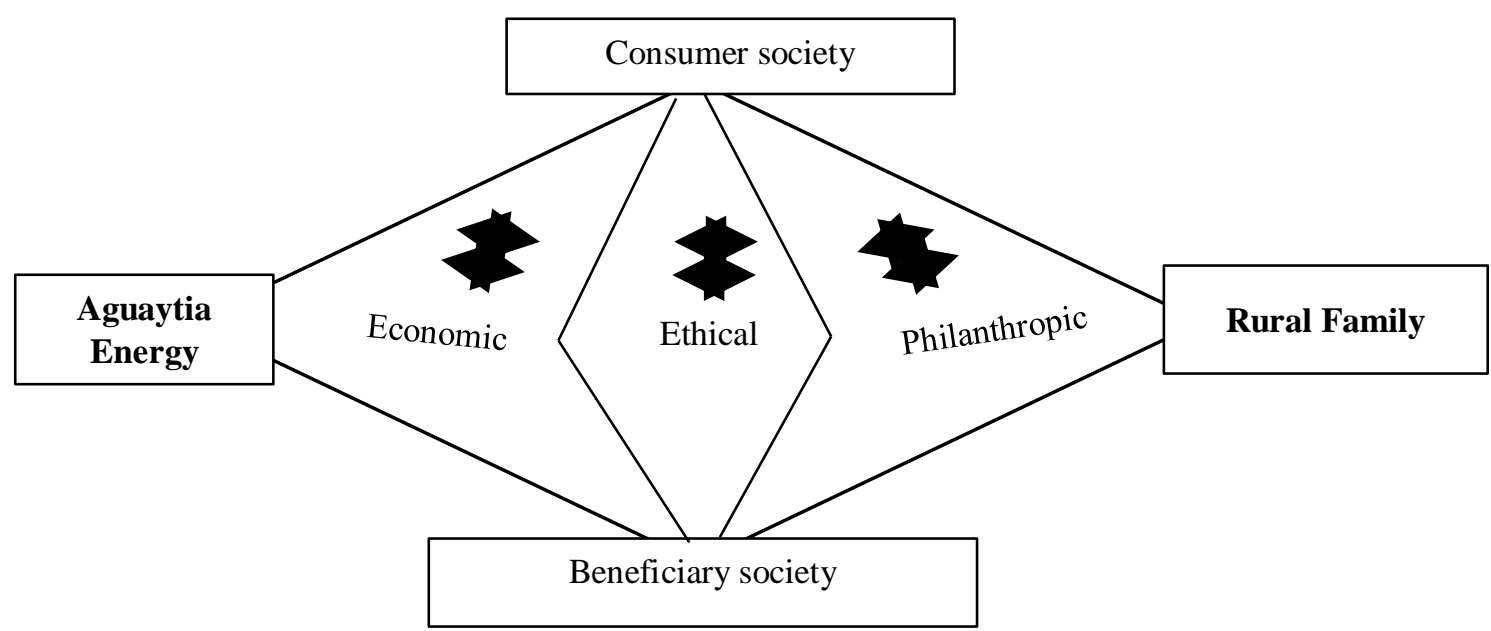

Figure 5. Type of Relationship between Aguaytía-Energy Maple Gas and Rural Families Source: Prepared by the authors.

The analysis of the data reveals the following characteristics of the relationship: (a) The relationship with families is integrated into the company's strategy. (b) The relationship with families allows the company to stay in the market and expand its consumer market. (c) The relationship with the company affects the short-term revenues of households. (d) Social responsibility is inherent to the company's policy. (e) Social responsibility contributes to sustainable development. (f) The company deliberately supports the families because of its commitment to society. Table 5 outlines this relationship in greater detail.

Table 5

Type of Relationship between Aguaytía Energy Company and Rural Families

\begin{tabular}{|c|c|c|c|}
\hline Category & $\begin{array}{c}\text { Code } \\
\text { (framework) }\end{array}$ & Code (evidence) & Evidence \\
\hline \multirow[t]{3}{*}{ Economic } & $\begin{array}{l}\text { Included in the } \\
\text { company's } \\
\text { strategy: } \\
\text { returns/cost } \\
\text { reduction }\end{array}$ & $\begin{array}{l}\text { Relationship with families } \\
\text { included in corporate } \\
\text { strategy }\end{array}$ & $\begin{array}{l}\text { "We are producing one hundred seventy- } \\
\text { three megawatts. Before the electricity was } \\
\text { sold to the national grid but now it stays in } \\
\text { the local market" (Manager 2, Aguaytía). }\end{array}$ \\
\hline & Stay in the market & $\begin{array}{l}\text { Relationship with families } \\
\text { allows companies to } \\
\text { remain in markets and } \\
\text { expand its consumer } \\
\text { market }\end{array}$ & $\begin{array}{l}\text { "The local mass market for liquefied gas } \\
\text { includes flat ferries and taxi cabs. People } \\
\text { who joined the program improved their } \\
\text { livelihoods" (Manager 1, Aguaytía). }\end{array}$ \\
\hline & Income promoted & $\begin{array}{l}\text { Impact on families' short- } \\
\text { term revenues }\end{array}$ & $\begin{array}{l}\text { "When they switched to gas, they could save, } \\
\text { on average, eight to ten extra soles (Peruvian } \\
\text { currency) a day" (Manager 2, Aguaytía). }\end{array}$ \\
\hline Ethical & $\begin{array}{l}\text { Company values } \\
\text { and rules (doing } \\
\text { what is right) }\end{array}$ & $\begin{array}{l}\text { SR is inherent to company } \\
\text { policy }\end{array}$ & $\begin{array}{l}\text { "We have always engaged in SR. We never } \\
\text { were a company that delegated SR to lower } \\
\text { third management. So we have to make a } \\
\text { contribution to our society" (Manager } 1 \text { ). }\end{array}$ \\
\hline
\end{tabular}


Table 5 (continued)

\begin{tabular}{llll}
\hline Category & \multicolumn{1}{c}{$\begin{array}{c}\text { Code } \\
\text { (framework) }\end{array}$} & \multicolumn{1}{c}{ Code (evidence) } & \multicolumn{1}{c}{ Evidence } \\
\hline Ethical & $\begin{array}{l}\text { Voluntary respect } \\
\text { for the social and } \\
\text { environmental } \\
\text { context }\end{array}$ & $\begin{array}{l}\text { SR as a contribution to "We started with communities near the } \\
\text { sustainable development }\end{array}$ & $\begin{array}{l}\text { "Werations area in Curimaná, Horizonte. It } \\
\text { takes several hours to reach Curimaná. No } \\
\text { power. People used to use candles. And now } \\
\text { (Manager } \\
\text { they have electricity" } \\
\text { Aguatía). }\end{array}$ \\
\hline $\begin{array}{l}\text { Philanthro } \\
\text { pic }\end{array}$ & $\begin{array}{l}\text { Discretionary, } \\
\text { voluntary }\end{array}$ & $\begin{array}{l}\text { The company deliberately "I was in Ayacucho in 1990, helping } \\
\text { provides support out of its } \\
\text { commitment to society }\end{array}$ & $\begin{array}{l}\text { orphanages ... I am convinced that SR is a } \\
\text { way of life, not for showing off" (Manager } \\
1, \text { Aguaytía). }\end{array}$ \\
\hline
\end{tabular}

Note. Source: Prepared by the authors.

\section{Comparing the Two Companies in the Extractive Sector}

In both cases these companies in the extractive sector have built a relationship with rural families under the beneficiary-society approach because their relationship is considered compensation for the damage caused or that may be caused to families by the companies' activity. In this sense, the relationship involves a collateral cost to the company because the relationship with the families is not part of the company's business. It is a relationship that benefits the families so as to avoid social conflicts. In turn, the families perceive themselves as beneficiaries of the companies in the extractive sector.

A similarity exists between these two companies, which have both adopted a beneficiary society approach. However, only in the case of Aguaytía there is a consumer society approach to the relationship. The company seeks to earn a profit, change the pattern of energy consumption among families, and transform them into consumers of its products. Both extractive companies engage in a philanthropic type of relationship because they make discretionary and voluntary contributions. There is also an ethics-driven company-family relationship that reflects the organizations' institutional values. Table 6 compares the approaches of Yanacocha and Aguaytía.

Table 6

Comparison of Categories between Yanacocha and Aguaytía Energy

\begin{tabular}{|c|c|c|c|c|}
\hline Category & $\begin{array}{c}\text { Code } \\
\text { (framework) }\end{array}$ & $\begin{array}{c}\text { Minera } \\
\text { Yanacocha }\end{array}$ & $\begin{array}{c}\text { Grupo } \\
\text { Aguaytía }\end{array}$ & Pattern \\
\hline \multirow{2}{*}{$\begin{array}{l}\text { Consumer } \\
\text { society }\end{array}$} & Company profits & $\mathrm{X}$ & $\mathrm{X}$ & $\mathrm{X}$ \\
\hline & $\begin{array}{l}\text { Company perceives families as attractive } \\
\text { market (clients) }\end{array}$ & & $\mathrm{X}$ & \\
\hline \multirow{4}{*}{$\begin{array}{l}\text { Beneficiary } \\
\text { society }\end{array}$} & Company affects people & $\mathrm{X}$ & $\mathrm{X}$ & $\mathrm{X}$ \\
\hline & Family meets its needs & $\mathrm{X}$ & $\mathrm{X}$ & $\mathrm{X}$ \\
\hline & Families get support & $\mathrm{X}$ & $\mathrm{X}$ & $\mathrm{X}$ \\
\hline & Collateral to business activities & $\mathrm{X}$ & & \\
\hline
\end{tabular}

Note. Source: Prepared by the authors. 
From a conceptual standpoint, the company and the families engage in four types of relationships: economic, legal, ethical, and philanthropic. In the cases reviewed here, the philanthropic relationship prevails. Companies in the extractive sector see the relationship between company and families as voluntary, discretionary, and driven by their strong sense of support to families who feel affected by the companies' operations. The companies' social initiatives address the families' main problems of poverty, unemployment, and poor health and education. Even when managers are aware that these issues are not part of the companies' business, they think that these issues must be considered. As a result, the company improves or maintains its legitimacy and image, and society benefits from corporate initiatives.

The second type of relationship found in the cases reviewed here is the ethical relationship that emerges when a company incorporates its relationship with families into its values, principles, and business rules. As a matter of principle, companies respect social, economic, and environmental rights. Aguaytía's respect for the community and the environment is manifested in the words of the SR manager: "Our economic initiatives seek to provide clean energy to communities, encourage environmental stewardship, care for people's health, and at the same time increase profit margins through reduced costs".

Yanacocha clearly also follows the principle of financially sustainable investments. The miner's project manager said, "Our investments in the areas impacted by the company should last beyond the company's period of intervention and operation". This kind of relationship has been tested by triangulating using the opinion of managers, official documents, and the views of rural families.

The economic relationship occurred only with one company; however, the interviews with managers allow us to deduce that the relationship with rural families has in both cases an indirect economic effect: a good relationship with rural families protects the company's operations in the areas where families live, thus reducing the eventual risk and cost of an interruption of business resulting from social conflicts. The triangulation method did not confirm the legal type of relationship, which was only taken into consideration for Yanacocha. Thus, even if national regulations require social investments (e.g., mining and gas canon royalties, solidarity funds, development trust funds, income tax breaks, social license, prior consultation with local communities), they are not considered to be the main reason for the relationship by either the managers or the rural families in the cases reviewed here. Two reasons account for this: the limited capacity of the state to enforce its own rules (weak enforcement) and the low effectiveness and impact of these social investments that, although required by law, are not perceived by the people. Table 7 compares the relationship types between Yanacocha and Aguaytía.

Table 7

Comparison of Type of Relationships between Yanacocha and Aguaytía Energy

\begin{tabular}{|c|c|c|c|c|}
\hline Category & Code Framework & $\begin{array}{c}\text { Minera } \\
\text { Yanacocha }\end{array}$ & $\begin{array}{c}\text { Grupo } \\
\text { Aguaytía }\end{array}$ & Pattern \\
\hline \multirow{2}{*}{ Economic } & Included in the company's strategy & & $\mathrm{X}$ & \\
\hline & Stay in the market & & $\mathrm{X}$ & \\
\hline Legal & $\begin{array}{l}\text { License, company follows } \\
\text { stakeholders' principles }\end{array}$ & $\mathrm{X}$ & & \\
\hline \multirow{2}{*}{ Ethical } & $\begin{array}{l}\text { Company values and rules (doing } \\
\text { what is right) }\end{array}$ & & $\mathrm{X}$ & \\
\hline & $\begin{array}{l}\text { Voluntary respect for the social and } \\
\text { environmental context }\end{array}$ & $\mathrm{X}$ & $\mathrm{X}$ & $\mathrm{X}$ \\
\hline
\end{tabular}

Note. Source: Elaborated by the authors. 


\section{Discussion and Conclusions}

The conceptual framework uses two approaches: one in which society is a consumer of the companies' goods and services, and the other in which society is a beneficiary of the companies. The relationship between the extractive sector companies and rural families is that of a beneficiary society. Families are seen as victims of corporate action, contrary to what might expected from the literature (Husted \& Salazar-Cantú, 2006; Prahalad \& Hart, 2008). Therefore, the main form of company intervention in their communities is through their SR programs to support social projects - not through considering society as a consumer of company goods and services. In the contrast, in the case of Aguaytía Energy managers do tend to see rural families as consumers of their product, natural gas. This finding is explained by the fact that families use natural gas for domestic purposes.

The results show that the relationship between the companies and rural families is ethical and traditional philanthropic, the latter being non-strategic philanthropic, through the approach wherein society is a beneficiary of business. This finding partially contradicts the statement of Porter and Kramer (2006), according to whom the relations between companies and society leading to social actions are motivated by strategic ethical and philanthropic considerations. Porter and Kramer (2002) hold that "philanthropy is increasingly used as a form of public relations or advertising to promote the image of a company" (p. 56). Although this approach indeed seems to be the case with the companies studied here, no strategic philanthropic relationship has yet been created. Companies are unable to improve their "competitive context, i.e., the quality of the business environment in the localities where they operate" (Porter \& Kramer, 2002, p. 59).

This study also shows that, through a number of SR programs, the extractive sector companies and the local rural families have built a philanthropic- and ethical-type relationship (as opposed to an economic- or legal-type of relationship). This finding contradicts Carroll's hierarchy. Carroll (1979, 1991, 2003, 2008) posited that the main reasons for corporate social initiatives are, in order of importance, economic, legal, ethical, and philanthropic. This study shows that ethical and philanthropic relationships are more notable in both cases addressed. Provided that philanthropy has no limit, this kind of relationship can be deeply unsatisfactory, and hence can lead to a permanent situation of latent conflict. The traditional philanthropy does not solve the main problems of the conflicts between extractive companies and rural communities. It is only hiding them.

Both the mining and hydrocarbon extractive industries have created social and environmental impacts that affect rural communities in many places, resulting in social conflicts that harm the communities in many ways, including loss of human life, the trampling of citizen rights, and irreparable environmental pollution (Bebbington, 2013; Davis \& Franks, 2014; Zarsky \& Stanley, 2013). For companies, the consequences were production overruns, declining investment, and bad corporate image. To manage social conflicts between extractive sector companies and rural communities, the companies have typically adopted the Harvard negotiation method (Fisher, Ury, \& Patton, 1991), which is based essentially on satisfying the plaintiffs' economic interests and expectations. Most schemes propounded by the government, such as trust funds, mining and energy canon (i.e., royalties), and compensation funds, assume an economic relationship between enterprises and rural families, as posited by Carroll (1979). Other mechanisms provided by the government, such as prior consultation and social license, are legal instruments in the second rung of Carroll's pyramid.

Finally, the discussion above clarifies the contribution of this research, which is two-fold. First, Carroll's pyramid of hierarchical types of relationships remains partially valid in that economic, legal, ethical and philanthropic relational aspects which are identified in the context of extractive operations taking place in territories wherein local communities live and carry out traditional socioeconomic activities. However, the relationships' order of importance differs from what Carroll proposed. For business managers, economic and legal motives drive their SR actions, whereas for families and communities at large, ethical and philanthropic motives are perceived as the basis for the very existence of a relationship. Both parties, therefore, hold an opposite view that leads to a conflictive relationship, 
which forces companies to adopt a society-as-beneficiary approach regarding their SR commitment and prevents companies from supporting activities that contribute to communities' long-term well-being and prosperity. Second, the results of this research give us a different perspective of the relationship between extractive sector companies and rural families: if the relationships the companies hope to create with families are to be based on philanthropic and ethical principles, then government conflict-management strategies should consider the potential of these elements. The solution to a conflict is not only to meet economic interests, which often results in a zero sum scenario, but also to construct a robust relationship based on trust, in other words, an ethical strategic-philanthropy approach that allows for a healthy transition from a society that perceives itself as a victim that must be compensated through pure philanthropy, to a society that develops the ability to partner with its business neighbor in order to leverage opportunities to improve well-being and prosperity.

\section{Limitations and future research}

The study includes some limitations that should be addressed in future research. The first shortcoming is that the study was conducted with only two extractive sector companies. The extractive industry is complex and dissimilar. The mining sector has a long history in Latin America, mainly in the Andean region. However, the hydrocarbon industry, especially natural gas, is a recent participant. It operates mainly in areas where native communities dwell in the Amazon jungle. This industry in the jungle is going through a learning process. In future research, studies could include additional extractive industries (i.e., mining, renewable energy, timber and hydrocarbons). The second limitation is that the rural families interviewed were not equally adapted to the recent changes spurred on by globalization and the market economy. Some rural families still maintain their traditions and values. Others have already adapted to the global market economy. In future research, the study could control for these differences among families. The third limitation is that more people from each of the families have to be interviewed in order to gain more points of view. For example, future research could include informants who were not the heads of household, in other words, women and children, in order to obtain a more comprehensive perspective from within the same family. The fourth limitation was that third parties external to the relationship between the business and family were not taken into consideration. The role and influence of social organizations, environmental movements and human rights watchdog groups were not taken into account. In future research the role of such external agents should be considered. Finally, the management of social conflicts was not directly investigated. However, the results throw new perspectives on social conflicts. In future research, it would be expedient to examine the social conflicts between mining companies and the rural and indigenous communities near their operations. The issue of conflict management using an ethical approach deserves further exploration.

\section{References}

Ahlstrom, D. (2010). Innovation and growth: How business contributes to society. Academy of Management Perspectives, 24(3), 11-24. https://doi.org/10.5465/amp.2010.52842948

Altman, B. W. (1998). Transformed corporate community relations: A management tool for achieving corporate citizenship. Business and Society Review, 102/103(1), 43-51. https://doi.org/10.1111/0045-3609.00024

Banco Central de Reserva del Perú. (2015). Memoria 2015. Retrieved from http://www.bcrp.gob.pe/docs/Publicaciones/Memoria/2015/memoria-bcrp-2015.pdf

Bhattacharya, C. B., \& Sen, S. (2003). Consumer-company identification: A framework for understanding consumers' relationships with companies. Journal of Marketing, 67(2), 76-88. https://doi.org/10.1509/jmkg.67.2.76.18609 
Bhattacharya, C. B., \& Sen, S. (2004). Doing better at doing good: When, why, and how consumers respond to corporate social initiatives. California Management Review, 47(1), 9-24. https://doi.org/10.2307/41166284

Bebbington, A. (2013). Industrias extractivas: Conflict social y dinámicas institucionales en la Región Andina. Lima, Peru: Instituto de Estudios Peruanos.

Bell, M. L., \& Emory, C. W. (1971). The faltering marketing concept. Journal of Marketing, 35(4), 3742. https://doi.org/10.2307/1250455

Carroll, A. B. (1979). A three-dimensional conceptual model of corporate social performance. Academy of Management Review, 4(4), 497-505. https://doi.org/10.5465/amr.1979.4498296

Carroll, A. B. (1991). The pyramid of corporate social responsibility: Toward the moral management of organizational stakeholders. Business Horizons, 34(4), 39-48. https://doi.org/10.1016/00076813(91)90005-g

Carroll, A. B. (1993). Business and society: Ethics and stakeholder management (2nd ed.). Cincinnati: South-Western Publishing.

Carroll, A. B. (2003). The four faces of corporate citizenship. Business and Society Review, 100(101), 1-7. https://doi.org/10.1111/0045-3609.00008

Carroll, A. B. (2008). A history of corporate social responsibility: Concepts and practices. In A. Crane, A. McWilliams, D. Matten, J. Moon, \& D. Siegel (Eds.), The Oxford handbook of corporate social responsibility (pp. 19-46). Oxford: Oxford University Press.

Castro, A. (2012). Familias rurales y sus procesos de transformación: Estudio de casos en un escenario de ruralidad en tensión. Psicoperspectivas, 11(1), 180-203. Retrieved from http://www.psicoperspectivas.cl/index.php/psicoperspectivas/article/viewFile/172/188. http://dx.doi.org/10.5027/psicoperspectivas-Vol11-Issue1-fulltext-172.

Coase, R. H. (1960). The problem of social cost. Journal of Law and Economics, 3(1), 1-44. Retrieved from http://www.jstor.org/stable/724810

Connelly, B. L., Ketchen, D. J., \& Slater, S. F. (2011). Toward a "theoretical toolbox" for sustainability research in marketing. Journal of the Academy of Marketing Science, 39(1), 86-100. https://doi.org/10.1007/s11747-010-0199-0

Corbin, J., \& Strauss, A. (2008). Basics of qualitative research: Techniques and procedure for developing grounded theory (3rd ed.). Thousand Oaks: Sage Publications.

Creswell, J. (2013). Research design. Qualitative, quantitative and mixed methods approach (4th ed.). Los Angeles: Sage Publications.

Damonte, G. (2008). The transnationalization of the mining industry in Peru and Bolivia. In G. Damonte, The constitution of political actors: Peasant communities, mining and mobilization in Bolivian and Peruvian Andes (pp. 135-174). Saarbrücken-Berlin: VDM Verlag.

Damonte, G., Kuramoto, J., \& Glave, M. (2014). Industrias extractivas y manejo de conflictos [Manual]. Peru: Grupo de Análisis para el Desarrollo (GRADE).

Daou, L., \& Sarkis, N. (2013). Giving back to the community, an obligation or an option today? Case of the educational sector in Lebanon. International Strategic Management Review, 1(1/2), 59-64. https://doi.org/10.1016/j.ism.2013.09.001 
Davis, R., \& Franks, D. (2014). Cost of company-community conflict in the extractive sector (Corporate Social Responsibility Initiative Report 66). Retrieved from https://www.hks.harvard.edu/mrcbg/CSRI/research/Costs\%20of\%20Conflict_Davis\%20\%20Franks.pdf

Defensoría del Pueblo. (2007, Noviembre 30). Conflictos sociales conocidos por la defensoría del pueblo (Unidad de Conflictos Sociales - Reporte de conflictos sociales $\mathrm{N}^{\circ} 45$ ). Retrieved from http://www.defensoria.gob.pe/modules/Downloads/conflictos/2007/conflictos_sociales45.pdf

Defensoría del Pueblo. (2015, Noviembre). Reporte de conflictos sociales $N^{o} 141$. Adjuntía para la Prevención de los Conflictos Sociales y la Gobernabilidad. Retrieved from http://www.defensoria.gob.pe/modules/Downloads/conflictos/2015/Reporte-Mensual-deConflictos-Sociales-N--141---Noviembre-2015.pdf

Deloitte. (2015). Tracking the trends 2016. The top 10 issues mining companies will face in the coming year. Retrieved from https://www2.deloitte.com/content/dam/Deloitte/global/Documents/Energy-and-Resources/gxer-tracking-the-trends-2016.pdf

Diener, K. W. (2013, June). The charitable responsibilities model of corporate social responsibility. Journal of Academic and Business Ethics, 7, 1-13. Retrieved from http://www.aabri.com/manuscripts/121341.pdf

Dorregaray, P. F. P. (2005). Visión panorámica de las actividades mineras en el Perú - 2005. Peru: CARE Perú Programa Fortalece. Retrieved from http://www.care.pe/pdfs/cinfo/libro/minera\%20final.pdf

Drucker, P. (1985). Innovation and entrepreneurship. New York: Harper \& Row.

Du, S., Bhattacharya, C. B., \& Sen, S. (2007). Reaping relational rewards from corporate social responsibility: The role of competitive positioning. International Journal in Research Marketing, 24(3), 224-241. https://doi.org/10.1016/j.ijresmar.2007.01.001

Du, S., Bhattacharya, C. B., \& Sen, S. (2010). Maximizing business returns to corporate social responsibility (CSR): The role of CSR communication. International Journal of Management Review, 12(1), 8-19. https://doi.org/10.1111/j.1468-2370.2009.00276.x

Ellen, P. S., Webb, D. J., \& Mohr, L. A. (2006). Building corporate associations: consumer attributions for corporate socially responsible programs. Journal of the Academy of Marketing Science, 34(2), 147-157. https://doi.org/10.1177/0092070305284976

Fisher, R., Ury, W., \& Patton, B. (1991). Getting to yes: Negotiating agreement without giving in (2nd ed.). Sydney: Century Business.

Freeman, R. E., \& Phillips, R. A. (2002). Stakeholder theory: A libertarian defense. Business Ethics Quarterly, 12(3), 331-350. https://doi.org/10.2307/3858020

Freeman, R. E., \& Reed, D. L. (1983). Stockholders and stakeholders: A new perspective on corporate governance. California Management Review, 25(3), 88-106. https://doi.org/10.2307/41165018

Freeman, R. E., Wicks, A. C., \& Parmar, B. (2004). Stakeholder theory and "the corporate objective revisited". Organization Science, 15(3), 364-369. https://doi.org/10.1287/orsc.1040.0066

Friedman, M. (1962). Capitalism and freedom. Chicago: University of Chicago Press.

Friedman, M. (1970, September 13). The social responsibility of business is to increase its profits. The New York Times Magazine, 33, 122-126. 
Garriga, E., \& Melé, D. (2004). Corporate social responsibility theories: Mapping the territory. Journal of Business Ethic, 53(1), 51-71. https://doi.org/10.1023/b:busi.0000039399.90587.34

Godfrey, P. C. (2005). The relationship between corporate philanthropy and shareholder wealth: A risk management perspective. Academy of Management Review, 30(4), 777-798. https://doi.org/10.5465/amr.2005.18378878

Guba, E., \& Lincoln, Y. (1989). Fourth generation evaluation. Newbury Park: Sage Publications.

Hasnas, J. (1998). The normative theories of business ethics: A guide for the perplexed. Business Ethics Quarterly, 8(1), 19-42. https://doi.org/10.2307/3857520

Hillebrand, B., Driessen, P. H., \& Koll, O. (2015). Stakeholder marketing: Theoretical foundations and required capabilities. Journal of the Academy of Marketing Science, 43(4), 411-428. https://doi.org/10.1007/s11747-015-0424-y

Hillman, A. J., \& Keim, G. D. (2001). Shareholder value, stakeholder management; and social issues: What's the bottom line? Strategic Management Journal, 22(2), 125-139. https://doi.org/10.1002/1097-0266(200101)22:2<125::aid-smj150>3.0.co;2-h

Husted, B. W., \& Salazar-Cantú, J. (2006). Taking Friedman seriously: Maximizing profits and social performance. Journal of Management Studies, 43(1), 75-91. https://doi.org/10.1111/j.14676486.2006.00583.x

Instituto Nacional de Estadística e Informática. (2015a). Perú: Anuario de estadísticas ambientales 2014. https://www.inei.gob.pe/media/MenuRecursivo/publicaciones_digitales/Est/Lib1197/

Instituto Nacional de Estadística e Informática. (2015b, Septiembre). Perú: Síntesis estadística 2015. Retrieved https://www.inei.gob.pe/media/MenuRecursivo/publicaciones_digitales/Est/Lib1292/libro.pdf

International Monetary Fund. (2015). Perspectivas económicas. Las Américas: el norte se recupera y el sur aún espera. Retrieved from: https://www.imf.org /external/spanish/pubs/ft/reo/2015/whd/pdf/wreo0415s.pdf

Kapelus, P. (2002). Mining, corporate social responsibility and the community: The case of Rio Tinto Richards Bay Minerals and the Mbonambi. Journal of Business Ethics, 39(3), 296-375. http://dx.doi.org/10.1023/A:1016570929359

Klein, J., \& Dawar, N. (2004). Corporate social responsibility and consumers' attributions and brand evaluations in a product-harm crisis. International Journal of Research in Marketing, 21(3), 203217. https://doi.org/10.1016/j.ijresmar.2003.12.003

Laczniak, G. R., \& Murphy, P. E. (2012). Stakeholder theory and marketing: Moving from a firm-centric to a societal perspective. Journal of Public Policy \& Marketing, 31(2), 284-292. https://doi.org/10.1509/jppm.10.106

Laplante, L. J., \& Spears, S. A. (2008). Out of the conflict zone: The case for community consent processes in the extractive sector. Yale Human Rights and Development Law Journal, 11(1), 69116. Retrieved from http://digitalcommons.law.yale.edu/yhrdlj/vol11/iss1/6

Lucas, R., \& Sargent, T. (1981). After Keynesian macroeconomics. In R. Lucas \& T. Sargent (Eds.), Rational expectations and econometric practice (pp. 295-319). Minnesota: The University of Minnesota Press.

Maddala, G., \& Miller, E. (1991). Microeconomics: Theory and applications. New York: McGraw-Hill. 
Maon, F., Lindgreen, A., \& Swaen, V. (2010). Organizational stages and cultural phases: A critical review and a consolidative model of corporate social responsibility development. International Journal of Management Reviews, 12(1), 20-38. https://doi.org/10.1111/j.14682370.2009.00278.x

McKenna, K. (2016). Corporate social responsibility and natural resource conflict (Routledge Research in Sustainability and Business). London and New York: Routledge.

Melé, D. (2008). Corporative social responsibility theories. In A. Crane, D. Matten, A. McWilliams, J. Moon, \& D. S. Siegel (Eds.), The Oxford handbook of corporative social responsibility (pp. 4782). Oxford: Oxford University Press.

Mihaljevic, M., \& Tokic, I. (2015). Ethics and philanthropy in the field of corporate social responsibility pyramid. Interdisciplinary Management Research, 15, 799-807.

Ministerio de Energía y Minas. (2015a). Boletín estadístico del subsector minero. Retrieved from http://www.minem.gob.pe/_publicacion.php?idSector=1\&idPublicacion=500

Ministerio de Energía y Minas. (2015b). Perú 2014: Anuario minero. Reporte estadístico. Retrieved from http://www.minem.gob.pe/_publicacion.php?idSector=1\&idPublicacion=501

Moffat, K., \& Zhang, A. (2014, March). The paths to social licence to operate: An integrative model explaining community acceptance of mining. Resources Policy, 39, 61-70. https://doi.org/10.1016/j.resourpol.2013.11.003

Nem Singh, J. (2012, January 9). The resource curse: Governing extractive industries in the global south. E-International Relations. Retrieved from http://www.e-ir.info/2012/01/09/the-myth-of-theresource-curse-governing-extractive-industries-in-the-global-south/

Norman, D., \& Lincoln, Y. (2005). The SAGE handbook of qualitative research. California: SAGE Publications.

Organismo Supervisor de la Inversión en Energía y Minería. (2008). Regulación del gas natural en el Perú. Estado del Arte. Retrieved from http://www2.osinerg.gob.pe Infotec/GasNatural/pdf/Regulacion_Gas_Natural_Peru.pdf

Parmar, B. L., Freeman, R. E., Harrison, J. S., Wicks, A. C., Colle, S., de, \& Purnell, L. (2010). Stakeholder theory: The state of the art. The Academy of Management Annals, 4(1), 403-445. https://doi.org/10.1080/19416520.2010.495581

Peloza, J., \& Shang, J. (2011). How can corporate social responsibility activities create value for stakeholders? A systematic review. Journal of the Academy of Marketing Science, 39(1), 117135. https://doi.org/10.1007/s11747-010-0213-6

Prahalad, C., \& Hart, S. (2008). The fortune at the bottom of the pyramid. Revista Eletronica de Estratégia \& Negócios, 1(2), 1-23. http://dx.doi.org/ 10.19177/reen.v1e220081-23

Porter, M. (1980). Competitive strategy: Techniques for analyzing industries and competitors. New York: Free Press.

Porter, M., \& Kramer, M. (2002). The competitive advantage of corporate philanthropy. Harvard Business Review, 80(12), 56-69. Retrieved from https://hbr.org/2002/12/the-competitiveadvantage-of-corporate-philanthropy

Porter, M., \& Kramer, M. (2006). Strategy and society: The link between competitive advantage and corporate social responsibility. Harvard Business Review, 84(12), 56-68. Retrieved from https://hbr.org/2006/12/strategy-and-society-the-link-between-competitive-advantage-andcorporate-social-responsibility 
Porter, M., \& Kramer, M. (2011). Creating shared value. Harvard Business Review, 89(1/2), 62-77. Retrieved from https://hbr.org/2011/01/the-big-idea-creating-shared-value

Roarty, M. (1997). Greening business in a market economy. European Business Review, 97(5), 244254. https://doi.org/10.1108/09555349710179898

Robin, D. P., \& Reidenbach, R. E. (1987). Social responsibility, ethics, and marketing strategy: Closing the gap between concept and application. Journal of Marketing, 51(1), 44-58. https://doi.org/10.2307/1251143

Safwat, A. M. (2015). Corporate social responsibility: Rewriting the relationship between business and society. International Journal of Social Sciences, 4(1), 85-97. https://doi.org/10.20472/ss2015.4.1.006

Schumpeter, J. (1939). Business cycles: A theoretical, historical and statistical analysis of the capitalist process. New York: McGraw Hill.

Sen, S., Bhattacharya, C. B., \& Korschun, D. (2006). The role of corporate social responsibility in strengthening multiple stakeholder relationships: A field experiment. Journal of the Academy of Marketing Science, 34(2), 158-166. https://doi.org/10.1177/0092070305284978

Stake, R. (1995). The art of case research. Thousand Oaks: Sage Publications.

Steiner, G. (1971). Business and society. New York: Random House.

Strauss, A. (1987). Qualitative analysis for social scientists. Cambridge: Cambridge University Press.

Superintendencia Nacional de Aduanas y de Administración Tributaria. (2015, Febrero 23). Informe mensual de exportaciones (Nota de Prensa $\mathrm{N}^{\circ}$ 039-2015). Retrieved from http://p.setodo.com/pravo/22025/index.html

Superintendencia Nacional de los Registros Públicos. (2016). Directorio Nacional de personas jurídicas. Retrieved from https://www.sunarp.gob.pe/dn-personas-juridicas.asp

Yin, R. K. (1994). Case study research: design and methods (Applied Social Research Methods). Newbury Park: Sage Publications.

Zarsky, L., \& Stanley. L. (2013). Can extractive industries promote sustainable development? A net benefits framework and a case study of the marlin mine in Guatemala. Journal of Environment \& Development, 22(2), 131-154. https://doi.org/10.1177/1070496513483131

\title{
Authors' Profiles
}

\author{
Jose Ventura \\ Universidad ESAN, Alonso de Molina, 1652, Monterrico, Surco, Lima, Peru. E-mail address: jventura@esan.edu.pe \\ Kety Jauregui \\ Universidad ESAN, Alonso de Molina, 1652, Monterrico, Surco, Lima, Peru. E-mail address: kjauregui@esan.edu.pe
}

